\title{
RELIGIOUS PLURALITY IN DAYAK BIDAYUH LARA SOCIETY (PORTRAIT OF INTER-RELIGIOUS HARMONY IN KENDAIE LUNDU VILLAGE, SARAWAK)
}

\author{
ZAKARIA EFEND I \\ Fakultas Ushuludin Adab dan Dakwah, Institut Agama Islam Negeri (IAIN) Pontianak. Jl. Letjend Soeprapto No. 19. Pontianak. \\ Email: zakariaefendi198@yahoo.co.id
}

\begin{abstract}
This study investigates the phenomena of plurality among the Dayak Bidayuh Lara community in Kendaie Lundu Village, Sarawak. Apart from that, it also describes the social and religious activities of the indigenous people that maintain the concept of tolerance. This study used qualitative methods by conducting observations and by using a descriptive approach as a research instrument. The study found that 1) as an indigenous community, the indigenous Dayak Bidayuh lara community in Kendaie Lundu Village are aware of the plurality of life in their environment, so that in carrying out social and religious activities, they live not in boundaries that separate between majority and minority communities. 2) There are some people with different religions from one family and live in one house. So that this reflects the exoticism of religious plurality in the Dayak Bidayuh Lara community; 3) as a community that inhabits the interior and border areas, inter-national fraternities are closely intertwined, social relations between the people of Malaysia and Indonesia are still established today.
\end{abstract}

KeY WoRDS: plurality, Bidayuh Lara Dayak tribe, religious harmony, tolerance

\section{PLURALITAS AGAMA PADA MASYARAKAT ADAT DAYAK BIDAYUH LARA (POTRET KERUKUNAN ANTAR UMAT BERAGAMA DI KAMPUNG KENDAIE LUNDU, SARAWAK)}

\begin{abstract}
Abstrak
Makalah ini menggambarkan pluralias yang terjadi pada masyarakat Dayak Bidayuh Lara di Kampung Kendaie Lundu, Sarawak. Selain itu, makalah ini juga mendeskripsikan kegiatan-kegiatan sosial dan keagamaan masyarakat adat di sana yang menjunjung tinggi toleransi. Penelitian ini menggunakan metode kualitatif dengan melakukan observasi, pengamatan, dan dengan menggunakan pendekatan deskriptif sebagai instrumen penelitian. Hasil penelitian; 1) sebagai masyarakat adat, masyarakat adat Dayak Bidayuh Lara di Kampung Kendaie Lundu sadar akan pluralitas dalam kehidupan di lingkungannya, sehingga dalam melakukan aktivitas sosial dan keagamaan, tidak menimbulkan jarak dan batasan antara masyarakat mayoritas dan minoritas; 2) masih banyak dijumpai orang-orang dengan agama yang berbeda namun masih satu keluarga dan hidup dalam satu rumah, sehingga hal tersebut mencerminkan keeksotisan dalam kemajemukan beragama pada masyarakat Dayak Bidayuh lara di sana; 3) sebagai masyarakat yang mendiami wilayah pedalaman dan perbatasan, persaudaraan serumpun lintas negara terjalin dengan erat, hubungan sosial masyarakat di Malaysia dan Indonesia masih terjalin sampai sekarang.
\end{abstract}

KATA KunCI: pluralitas, suku Dayak Bidayuh Lara, kerukunan umat beragama, toleransi

* Naskah diterima Maret 2021, direvisi April 2021, dan disetujui untuk diterbitkan Mei 2020

Dialog, 44(1), 2021, 75-88

https://jurnaldialog.kemenag.go.id,p-ISSN: 0126-396X, e-ISSN: 2715-6230

This is open access article under CC BY-NC-SA-License

(https://creativecommons.org/license/by-nc-sa/4.0/)

Dialog Vol. 44, No.1, Juni 2021 


\section{A. Pendahuluan}

Kampung Kendaie Lundu merupakan nama sebuah desa di pedalaman Sarawak Malaysia, yang terletak tepat di perbatasan antara Malaysia dan Indonesia. Jarak antara Kampung Kendaie Lundu dengan ibu kota Sarawak, Kuching adalah 103 kilometer dan bisa ditempuh selama kurang lebih tiga jam perjalanan. Kampung Kendaie Lundu berbatasan langsung dengan Indonesia dan pemukiman terdekat di Indonesia adalah Aruk di Kabupaten Sambas. Kampung Kendaie Lundu hanya berjarak kurang lebih tiga kilometer dari garis perbatasan Malaysia dan Indonesia.

Masyarakat yang mendiami Kampung Kendaie Lundu adalah orang-orang Dayak dari sub suku Dayak Bidayuh Lara sama seperti masyarakat yang mendiami Aruk di Indonesia. Suku Dayak menurut seorang antropolog (Lotaan, 1975) dalam bukunya yang berjudul "Hukum Adat dan Adat Istiadat Kalimantan barat" menyebutkan bahwa Suku Dayak terdiri dari 6 suku besar dan 405 sub suku kecil yang menyebar di seluruh Kalimantan. Selain itu, Kampung Kendaie Lundu juga dihuni sub suku Dayak yang lain, di antaranya dari bangsa Iban, Selako, Bakati dan Melayu Malaysia. Selain suku asli tersebut, di Kampug Kendaie Lundu juga terdapat beberapa pendatang dari Indonesia yang sudah lama menetap di sana dan menjadi waga negara Malaysia seperti orang-orang Bugis Makassar dan orang Sunda dari Jawa Barat.

Karena letaknya yang berada tepat di daerah perbatasan, secara geografis Kampung Kendaie Lundu merupakan daerah perbukitan. Mayoritas masyarakat Kampung Kendaie Lundu bekerja sebagai peladang dan berkebun. Sebagian masyarakat di sana juga bekerja di perusahaan perkebunan sawit, sebagian lagi merantau ke kota untuk bekerja di kantor-kantor swasta dan kantorkantor pemerintahan di kota-kota besar seperti Kuching, Sabah, Miri, dan Kuala Lumpur.

Kampung Kendaie Lundu menjadi daerah dengan masyarakat yang majemuk. Mayoritas masyarakat di sana beragama Katolik dan Kristen, sebagian lagi beragama Islam, namun jumlahnya tidak lebih dari 70 orang yang terdiri dari orangorang Melayu dan orang-orang Dayak yang sudah menjadi mualaf. Pada dasarnya, masyarakat Kampung Kendaie Lundu memiliki banyak kesamaan dengan masyarakat Indonesia di perbatasan. Hal ini dikarenakan mayoritas masyarakat asli di sana berasal dari rumpun suku yang sama, yaitu Suku Dayak. Meskipun Islam menjadi minoritas, namun tingkat toleransi yang terjalin antar umat beragama dalam kehidupan sosial sehari-hari berlangsung dengan harmonis.

Islam masuk dan menjadi keyakinan yang di anut oleh sebagian masyarakat Kampung Kendaie Lundu di kalangan orang-orang Dayak karena beberapa faktor, antara lain dikarenakan oleh faktor pernikahan dengan pemeluk agama Islam dari suku yang berbeda dan karena faktor sukarela dimana seseorang telah mendapat hidayah menurut ajaran dalam Islam. Selain itu, Islam juga menjadi agama yang dipeluk oleh masyarakat asli dari suku Melayu. Hidup di pedalaman dan jauh dari akses kota membuat pluralitas yang terjalin pada masyarakat tumbuh secara alami dengan diajarkan oleh para orangtua dan diwariskan secara turun-temurun. Pluralitas tersebut mencakup kerukunan antar umat beragama, suku, dan budaya.

Pluralitas juga dikenal dengan istilah pluralisme. Menurut Shihab (Shihab, 1999, h. 4143), pengertian pluralisme adalah sikap toleransi untuk menahan diri agar potensi konflik dapat ditekan, dan pluralisme sesungguhnya tidak semata-mata menunjuk pada kenyataan tentang adanya kemajemukan, namun adanya keterlibatan aktif terhadap kenyataan kemajemukan tersebut. Bahwa tiap pemeluk agama dituntut bukan saja mengakui keberadaan dan hak agama lain, tetapi terlibat dalam usaha memahami perbedaan dan persamaan guna tercapainya kerukunan. Hal ini menjadi landasan dan pedoman hidup masyarakat Kampung Kendaie Lundu untuk saling menghormati dan saling menghargai dalam setiap perbedaan.

Pluralisme seperti yang dijelaskan oleh Liliweri (Liliweri, 2009) dalam bukunya yang berjudul "Prasangka \& Konflik, Komunikasi Lintas Budaya Masyarakat Multikultural", terdiri dari tiga makna yaitu, pluralisme jika dihubungkan dengan konsep lain (pluralism ethnic, pluralism political, struktur kekuasaan yang pluralistik, model pluralis, dual plurality theory, pluralism media), makna pluralisme sebagai doktrin, dan makna plularisme dalam ilmu pengetahuan. Dari pengertian tersebut maka praktik pluralisme yang terjadi di Kampung Kendaie Lundu termasuk dalam pluralisme etnik dimana masyarakat mengakui koeksistensi atau 
pengakuan terhadap kesetaraan sosial dan budaya antara beragam kelompok etnik yang ada dalam masyarakat Kampung Kendaie Lundu.

Selain potret pluralitas yang harmonis, orangorang Dayak yang sudah memeluk Islam di sana juga teguh dalam mempertahankan identitasnya dan tidak terpengaruh dengan isu yang berkembang di masyarakat luas yang menyangkut identitas sukunya setelah berpindah agama. Dalam memahami identitasnya, orang-orang Dayak yang sudah memeluk Islam menolak untuk disebut sebagai orang Melayu seperti anggapan yang pernah dijelaskan oleh Amilda (Amilda, 2011), bahwa Islam sebagai agama sekaligus menjadi dasar dari sistem nilai yang menjadi pedoman dari etnis mayoritas, yaitu Melayu. Islam juga menjadi lambang identitas dari etnis Melayu. Sebagai sebuah identitas, Islam juga dijadikan acuan untuk menempatkan kepercayaan lain sebagai subdominan, yang umumnya dianut oleh masyarakat minoritas harus menyesuaikan diri dengan sistem nilai dominan tersebut.

Potret pluralitas antar umat beragama di Kampung Kendaie Lundu terjalin dengan indah dalam kehidupan sehari-hari. Dalam melaksanakan kegiatan keagamaan setiap tahun sperti hari besar agama Idul Fitri dan Natal, masyarakat di sana menjunjung tinggi sikap gotong-royong, masyarakat akan saling membantu dalam menyiapkan tempat-tempat yang akan digunakan untuk ibadah seperti membersihkan dan menghias gereja ketika Natal atau membersihkan dan memperindah surau ketika datang bulan Ramadhan dan Idul Fitri. Meskipun mereka berbaur dalam melakukan kegiatan pada hari besar agama, mereka menyadari bahwa apa yang mereka lakukan bukan sebagai bentuk untuk mengikuti keyakinan saudara-saudara mereka, akan tetapi mereka hanya berupaya untuk saling membantu dan berbagi kebahagiaan.

Potret pluralitas lainnya adalah bahwa masih dijumpai keluarga yang tinggal satu atap namun menganut keyakinan berbeda. Hal seperti ini bagi masyarakat di sana sudah biasa karena memang tidak ada paksaan dari siapapun untuk menganut keyakinan dan kepercayaan, bahkan dari orangtua. Hal tersebut bukan dikarenakan kurangnya pengetahuan terhadap agama, namun bagi mereka hal itu adalah upaya untuk memberi kebahagiaan kepada saudara dan keluarganya, bahkan dalam memberikan kebebasan memeluk agama. Prinsip hidup kekeluargaan masyarakat Kampung Kendaie Lundu ini yang membuat konflik tidak pernah terjadi sampai sekarang.

Dari pluralitas yang sudah menjadi prinsip hidup sehari-hari, maka masyarakat Kampung Kendaie Lundu tumbuh dan hidup sebagai masyarakat sosial yang multikultural. Multikulturalisme sendiri mempunyai dua pengertian, pertama adalah konsep yang menjelaskan dua perbedaan dengan makna yang saling berkaitan. (1) Multikulturalisme sebagai kondisi kemajemukan kebudayaan atau pluralisme budaya dari suatu masyarakat. Kondisi ini dapat diasumsikan dapat membentuk sikap toleransi. (2) Multikulturalisme merupakan seperangkat kebijakan pemerintah pusat yang memberikan perhatian kepada suatu kelompok etnik atau suku bangsa. Kedua, multikulturalisme merupakan konsep sosial yang diintroduksi ke dalam pemerintahan agar pemerintah dapat menjadikannya sebagai kebijakan pemerintah, karena hanya pemerintah yang dianggap sangat representatif ditempatkan di atas kepentingan maupun praktik budaya dari semua kelompok etnik dari suatu bangsa. Akibatnya setiap kebijakan pemerintah diharapkan mampu mendorong lahirnya sikap apresiasi, toleransi, prinsip kesetaraan antara pelbagai kelompok etnik, termasuk kesetaraan bahasa, agama, atau praktik budaya lainnya (Liliweri, 2009).

Meskipun agama mempunyai peranan di dalam masyarakat sebagai kekuatan yang mempersatukan, mengikat dan melestarikan, namun ia juga mempunyai fungsi lain. Memang agama mempersatukan kelompok pemeluknya sendiri begitu kuatnya sehingga apabila ia tidak dianut oleh seluruh atau sebagian besar anggota masyarakat, ia bisa menjadi kekuatan yang menceraiberaikan, memecah belah, bahkan menghancurkannya. Disamping itu, agama tidak selalu memainkan peranan yang bersifat memelihara dan menstabilkan. Khususnya pada saat terjadi perubahan besar di bidang sosial dan ekonomi, agama sering memainkan peranan yang bersifat kreatif, inovatif, dan bahkan bersifat revolusioner (Elizabeth, 1992). Pengertian agama ini agaknya terlalu berlebihan bagi paham pluralitas, terutama pada masyarakat awam yang tinggal berbaur dengan keberagaman agama 
seperti masyarakat di Kampung Kendaie Lundu.

Dengan temuan-temuan yang sudah dijelaskan di atas, maka fenomena tersebut menarik untuk disampaikan pada khalayak umum. Dimana pluralisme antar umat beragama terjalin dengan harmonis dalam kehidupan seharihari. Atas dasar tersebut, penelitian ini bertujuan untuk mendeskripsikan kerukunan antar umat beragama dan toleransi yang menjadi pedoman hidup Masyarakat Dayak Bidayuh Lara agar dapat dijadikan contoh oleh masyarakat luas sebagai bagian dari masyarakat internasional. Khusunya oleh masyarakat di daerah perkotaan yang hidup berbaur dengan keberagaman yang lebih besar dan juga berkaitan langsung dengan perkembangan isu-isu yang menyangkut sara yang berkembang seiring dengan kemajuan teknologi dan menyebar dengan cepat di mediamedia online.

\section{B. Metode Penelitian}

Artikel ini merupakan hasil observasi lapangan dari pengalaman hidup dan tinggal bersama masyarakat adat Dayak Bidayuh Lara di Kampung Kendaie Lundu Sarawak selama satu bulan dalam kegiatan Program Pengabdian pada Masyarakat (PPM) internasional bersama dengan teman-teman dari IAIN Pontianak, IAIN Bengkulu, dan IAIN Palopo di tahun 2017 bekerjasama dengan Lembaga Dakwah Hikmah di Kuching. Dengan mengikuti aktivitas seharihari masyarakat Dayak Bidayuh Lara penulis melihat langsung praktik toleransi yang harmonis dalam kehidupan sehari-hari. Hal-hal menakjubkan tentang toleransi yang belum pernah penulis lihat sebelumnya dapat penulis temukan di sini, bahkan mengikutinya selama satu bulan. Toleransi tersebut mencakup segala aspek kehidupan masyarakat Dayak Bidayuh Lara, mulai dari kehidupan beragama, kehidupan sosial budaya, dan gotong-royong dalam menjalankan aktivitas kehidupan sosial sehari-hari.

Penelitian ini sendiri menggunakan pendekatan kualitatif. Menurut Bogdan dan Taylor yang dikutip oleh Lexy J. Moleong, "metodologi kualitatif adalah prosedur penelitian yang menghasilkan data deskriptif berupa katakata tertulis atau lisan dari orang-orang dan perilaku yang dapat diamati", (Moleong, 2015). Menurut Sukmadinata (Sukmadinata, 2013), bahwa "penelitian kualitatif (qualitative research) adalah suatu penelitian yang ditujukan untuk mendeskripsikan dan menganalisis fenomena, peristiwa, aktivitas sosial, sikap, kepercayaan, persepsi, pemikiran orang secara individual maupun kelompok".

Menurut S. Margono bahwa "penelitian kualitatif bersifat induktif, artinya peneliti membiarkan permasalahan-permasalahan muncul dari data atau dibiarkan terbuka untuk interpretasi. Data dikumpulkan dengan pengamatan secara teliti, mencakup deskripsi dalam konteks detail, disertai catatan-catatan hasil wawancara yang mendalam, serta hasil analisis dokumen dan catatan-catatan. Pendekatan kualitatif dimulai dengan berpikir deduktif untuk menurunkan hipotesis, kemudian melakukan pengujian lapangan. Kesimpulan atau hipotesis tersebut ditarik berdasarkan data empiris" (Margono, 2005).

Pengalaman berharga yang penulis dapatkan selama melakukan kegiatan di daerah perbatasan menjadikan bekal berharga dalam menulis makalah ini. Dengan hadirnya makalah ini penulis bertujuan untuk menggambarkan dan mendeskripsikan pluralitas pada masyarakat adat Dayak Bidayuh Lara. Khususnya tentang potret toleransi antar umat beragama dalam praktik menjalankan keyakiannya sesuai ajaran agama yang mereka peluk agar dapat dijadikan contoh dan dipelajari oleh masyarakat luas.

\section{Gambaran Umum}

Kampung Kendaie Lundu merupakan nama sebuah desa yang terletak di kota kecil Lundu di pedalam Sarawak. Kampung Kendaie Lundu berjarak 23 kilometer dengan pusat kota Lundu dan berjarak 103 kilometer dari ibukota Sarawak, Kuching. Secara geografis yang diunggah dalam Malaysia Postcode Search dengan postcode 94500, Kampung Kendaie Lundu terletak pada Latitude 1.671364 dan Longtitude 109.8519689. Kampung Kendaie Lundu merupakan daerah perbukitan, sebagian besar wilayahnya menjadi perkebunan sawit dan sebagian lagi masih alami menjadi hutan belantara.

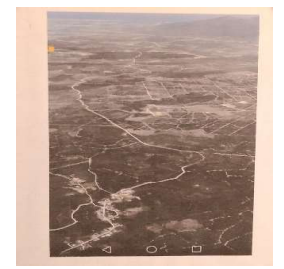

Gambar 1, Peta Kampug Kendaie 
Dengan daerah pemukiman terdekat di Indonesia, Kampung Kendaie Lundu hanya berjarak 26 kilometer dari Aruk di Kabupaten Sambas, sehingga ikatan persaudaraan serumpun lintas negara masih terjalin dengan erat sampai sekarang. Kampung Kendaie Lundu juga menjadi tempat asal bagi Suku Dayak Bidayuh Lara, sehingga seperti diketahui mayoritas masyarakat di sana adalah orang-orang Dayak dari sub suku Dayak Bidayuh Lara. Selain itu, di Kampung Kendaie Lundu juga dihuni oleh orang-orang dari sub suku Dayak Selako, sub suku Dayak Iban, sub suku Dayak Bakati, dan Melayu Malaysia. Mayoritas penduduk Kampung Kendaie Lundu adalah pemeluk agama Katolik dan Kristen, sebagian lagi memeluk agama Islam. Kemajemukan tersebut menjadikan kampung Kendaie Lundu sebagai sebuah kampung dengan tingkat pluralitas yang tinggi.

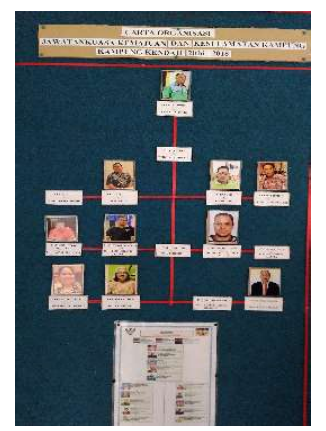

Gambar 2, Carta Organisasi Kampung Kendaie

Kampung Kendaie Lundu dihuni oleh 80 kepala keluarga dan jumlah masyarakat seluruhnya adalah 480 orang. Dengan jumlah masyarakatnya yang masih tergolong sedikit, di Kampung Kendaie Lundu menjadi sebuah kampung dengan suasana yang sepi baik siang dan malam hari. Karena sebagian besar penduduknya pergi berkebun pada siang hari dan malam menjadi waktu istirahat, sehingga kegiatan-kegiatan sosial hanya berlangsung sebentar ketika sore hari menjelang magrib atau pada hari libur seperti hari minggu dan tanggal merah. Sumber utama ekonomi masyarakat Kampung Kendaie Lundu bekerja di ladang kelapa sawit milik perusahaan dan perkebunan sawit milik pribadi. Sebagian lagi juga bekerja di kantor pemerinatahan dan swasta di kota-kota.

Sebagai orang kampung, pada umumnya masyarakat Kampung Kendaie Lundu sangat terbuka dengan orang asing yang datang ke wilayah mereka bermukim. Meskipun untuk menjangkau daerah ini tergolong cukup sulit karena harus melewati jalan berbukit dan terjal melewati perkebunan sawit, selain itu juga tidak ada transportasi umum yang bisa mengantar ke sana. Bagi orang asing yang baru pertama kali datang ke Kampung Kendaie Lundu juga akan sedikit dikejutkan dengan keberadaan banyaknya anjing-anjing peliharaan warga yang bebas berkeliaran. Karena memang hampir semua penduduk Kampung Kendaie memelihara anjing lebih dari satu dalam setiap rumah. Hal ini bertujuan sebagai antisipasi keamanan kampung dan juga sebagai teman untuk berkebun. Sebagai binatang yang memiliki tingkat kesetiaan yang tinggi terhadap majikannya, anjing menjadi peliharaan yang paling efektif untuk diajak berkebun, selain sebagai kawan juga sebagai pelindung karena memang perkebunan penduduk jauh dari pemukiman dan untuk mengantisipasi hal-hal yang tidak diinginkan.

Dalam menjalankan keyakinan agama yang dianut oleh masyarakat Kampung Kendaie, terdapat dua Gereja yang digunakan sebagai tempat ibadah oleh masyarakat yang beragama Kristen dan Katolik. Di Kampung Kendaie juga terdapat sebuah surau yang digunakan untuk ibadah oleh masyarakat yang beragama Islam. Selain sebagai tempat ibadah, surau di sana juga menjadi sarana untuk berkumpul, belajar mengajar, dan tempat tinggal bagi para pendatang yang sedang menjalankan tugas untuk mengajarkan agama Islam. Meskipun sudah tersedia surau dengan berbagai fasilitasnya, masyarakat setempat, baik yang beragama Islam dan beragama selain Islam sangat terbuka dengan menawarkan untuk menginap di rumah mereka jika sedang bosan di surau. Tentu hal ini menjadi bukti prinsip pluralitas masyarakat di sana telah melebur dan menjadi bagian dari kehidupan masyarakat Kampung Kendaie Lundu.

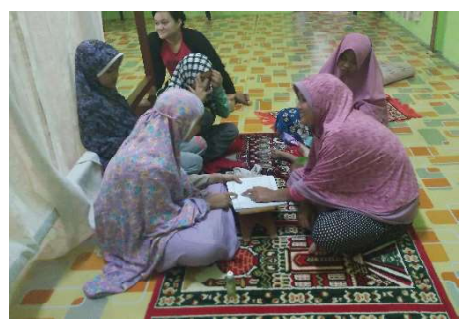

Gambar 3, Ibu-ibu muslim belajar mengaji di temani saudaranya yang non muslim 
Islam memang sudah menjadi bagian dari agama yang dipeluk oleh masyarakat di sana. Namun dalam menjalankan ajaran agama Islam, kebanyakan orang-orang yang sudah memeluk agama Islam di sana belum tahu tata cara sholat, bacaan sholat, dan mengaji. Hal ini dialami oleh semua anak-anak hingga orang-orang dewasa, tidak adanya guru agama Islam yang mengajarkan agama Islam secara rutin dan terus menerus menjadikan masyarakat yang beragama Islam sangat memprihatinkan. Dengan hal tersebut maka lembaga Hikmah Kuching mempunyai misi untuk mengirimkan guru agama Islam, hal ini dilakukan sebagai upaya Lembaga Dakwah Hikmah untuk memberi kontribusi nyata bagi dakwah Islam di pedalaman Sarawak.

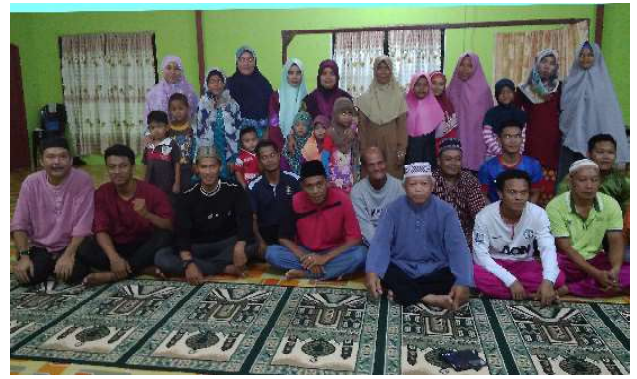

Gambar 4, Masyarakat dan perwakilan Lembaga Dakwah Hikmah

Hal itu juga yang membuka kesempatan bagi pelajar Indonesia untuk belajar mengabdi pada realitas di lapangan dengan mengajarkan seputar agama Islam kepada orang-orang Islam yang minim pengetahuan tentang Islam, bahkan yang menyangkut pengetahuan dasar. Selama proses kegiatan satu bulan banyak dijumpai fakta-fakta menarik yang menyangkut pluralitas kehidupan masyarakat Kampung Kendaie Lundu. Ketika proses belajar-mengajar tentang agama Islam, justru banyak anak-anak yang beragama Katolik dan Kristen ikut melihat dan belajar dengan bertanya seputar tema yang sedang diajarkan. Menariknya lagi, para orangtua dari mereka tidak melarang, mereka justeru menyuruh anakanaknya untuk ikut meramaikan kegiatankegiatan yang diadakan selama satu bulan. Dan selama satu bulan tersebut, masyarakat di Kampung Kendaie Lundu dari anak-anak, orangorang dewasa, dan para orangtua ikut meramaikan surau yang menjadi tempat belajar mengajar agama Islam. Mereka dengan senang hati melihat dan memberi semangat, bahkan sesekali bertanya seputar agama Islam. Menurut para orangtua, hal seperti ini sudah biasa. Bahkan sebelum kedatangan kami di sana, pada tahun 2016 juga ada rombongan pelajar dari Indonesia yang bekerjasama dengan Lembaga Dakwah Hikmah untuk menjalankan misi yang sama dan mereka juga menyambut dengan penuh suka cita.

\section{Toleransi Sebagai Prinsip Hidup Masyarakat Plural Kampung Kendaie LUNDU}

Suku Dayak menjadi penduduk mayoritas yang tinggal di Pulau Borneo, baik di Kalimantan dan Malaysia bagian Sarawak. Namun dengan arus globalisasi yang begitu pesat kini orang-orang Dayak berangsur meninggalkan kampung halamannya dengan berbagai alasan seperti sekolah, bekerja dengan merantau ke tempattempat strategis seperti kota-kota besar. Dalam memahami orang Dayak, kita sering mendengar ungkapan bahwa orang Dayak adalah orangorang yang tinggal di hutan dan garang karena mereka terisolir dari dunia luar. Namun pada nyatanya anggapan seperti ini sudah kuno dan ketinggalan zaman, padahal orang Dayak saat ini sudah maju seperti orang-orang dari suku bangsa dan dari daerah lain.

Ada banyak ungkapan dan konotasi yang melekat pada Orang Dayak seperti orang udik, orang terasing, orang kampung, orang yang makan orang, dan bahkan disebut sebagai orang yang belum bisa tulis menulis. Orang Dayak hidup dalam rumah panjang secara bersama dan dalam kehidupan yang berpindah-pindah dari satu hutan ke hutan lain, dari gunung atau lembah ke gunung atau lembah lain. Bahkan orang Dayak masih dianggap sebagai penyembah berhala seperti pohon besar atau batu (Rufinus, 2000). Pendapat di atas tentu tidak tepat diungkapkan pada orang-orang Dayak saat ini meskipun tidak bisa dipungkiri sebagai ungkapan yang berkembang di masyarakat luas tentang orang Dayak di masa lampau.

Dengan perkembangan globalisasi yang begitu pesat komunitas lokal ini telah pula merespon masuknya globalisasi ini dengan tidak hanya menjadi obyek yang pasif tetapi juga berperan aktif memanfaatkan pengaruh globalisasi untuk memenuhi kebutuhankebutuhan mereka dalam kehidupan modern yang semakin besar tantangannya. Dengan 
memanfaatkan produk-produk teknologi modern seperti handphone, televisi, dan antena parabola tersebut untuk pemenuhan kebutuhan hidupnya, masyakarat lokal telah pula mampu menjadi aktor dalam kehidupannya. Tentu saja pengaruhpengaruh luar sangat kental memengaruhi komunitas lokal ini. Tetapi di antara pengaruhpengaruh luar yang datang melalui teknologi modern tersebut tidak selalu bernilai negatif tetapi juga bernilai positif. Pengaruh-pengaruh yang bernilai positif inilah sebenarnya yang menjadi tujuan utama dalam proses identifikasi identitas etno-religio pada masyarakat Dayak (Zaenuddin, 2009).

Toleransi sebagai prinsip hidup masyarakat kampung Kendaie Lundu dalam menanggapai arus globalisasi yang perlahan masuk ke daerahnya, baik diterima melalui teknologi atau di bawa oleh pendatang yang bermukim di daerah mereka tidak membuat hubungan sosial terhambat. Meskipun sebagai orang Kampung yang jauh dari keramaian seperti di daerah perkotaan. Masyarakat Kampung Kendaie Lundu paham dengan sikap toleransi, toleransi bagi mereka yaitu saling menerima dan menghargai dalam segala perbedaan yang menyangkut suku, budaya, dan agamanya. Isu-isu yang berkaitan dengan intoleransi yang berkembang di masyarakat luas tidak berpengaruh bagi masyarakat Kampung Kendaie Lundu. Bagi masyarakat di sana, toleransi sudah menjadi bagian dalam hidup dan di ajarkan secara turuntemurun, sehingga anak-anak di sana tumbuh dengan karakter toleran yang kuat dalam menanggapi segala aspek perbedaan dengan dirinya.

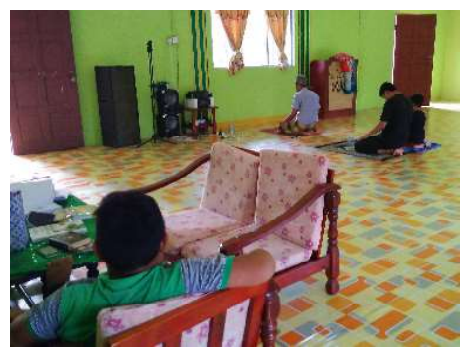

Gambar 5, Seorang anak non muslim menunggu temannya sholat

Seperti halnya dengan datangnya para mahasiswa yang mengemban misi untuk mengajarkan agama Islam sebagai agama yang dipeluk oleh masyarakat minoritas di sana. Masyarakat adat Dayak Bidayuh Lara yang masyoritas belum memeluk Islam justru menyambut dengan senang hati kedatangan kami, mereka menyediakan segala informasi yang kami butuhkan dan bersedia menemani semua kegiatan selama kami berada di sana. Mereka juga menganggap kami sebagai anak angkat dengan memperlakukan kami seperti keluarga mereka sendiri. Hampir semua masyarakat kampung menyambut dan bersuka cita atas kedatangan kami meskipun mereka tahu bahwa kedatangan kami adalah untuk mengajarkan agama Islam yang menjadi agama yang dipeluk oleh penduduk minoritas di sana.

Para mahasiswa ini dikirim oleh Lembaga Dakwah Hikmah Kuching yang bekerjasama dengan Perguruan Tinggi Islam (PTKIN) di Indonesia yang diinisiasikan oleh Institut Agama Islam Negeri (IAIN) Pontianak melalui pejabat Wakil Rektor III yang menangani kerjasama dan kemahasiswaan yang saat itu dijabat oleh Dr, Zaenuddin, MA. Sebagai mahasiswa dari latar belakang keilmuan yang berbeda namun dalam satu naungan di bawah Perguruan Tinggi Islam Indonesia dan juga sebagai umat Islam sendiri, bekal pemahaman yang dibawa adalah mengembalikan hakikat toleransi dalam kacamata Islam. Sebab istilah toleransi ini pada dasarnya tidak terdapat dalam Islam, akan tetapi termasuk istilah modern yang lahir dari Barat sebagai respon dari sejarah yang meliputi kondisi politis, sosial, dan budaya yang khas dengan berbagai penyelewengan dan penindasan (Bakar, 2015).

Toleransi dalam praktiknya masyarakat Kampung Kendaie Lundu yang mayoritas tidak beragama Islam juga turut mengayomi masyarakat minoritas dengan memberikan fasilitas dan membantu dalam kegiatan-kegiatan masyarakat yang beragama Islam, seperti ketika hari raya dan acara pernikahan. Tentu hal ini menjadi fenomena yang menarik, dimana saat ini banyak sekali terjadi isu-isu intoleran dengan mengatasnamakan agama dan suku tertentu dan berbahaya bagi persatuan dan persaudaraan. Masyarakat Adat Dayak Bidayuh Lara di Kampung Kendaie Lundu menjadi contoh nyata bagi persaudaraan dalam keberagaman.

Pluralitas budaya yang merajut toleransi di Kampung Kendaie Lundu juga terjadi ketika diadakan pekan Gawai Dayak sebagai acara adat 
Dayak untuk mensyukuri hasil bumi mereka. Masyarakat Dayak yang mayoritas tidak beragama Islam akan memberikan ruang khusus kepada saudara-saudara mereka yang beragama Islam untuk turut serta dalam kegiatan mereka. Dalam melaksanakan acara adat ini orang-orang Dayak yang tidak beragama Islam akan mempersilahkan saudara mereka yang sudah memeluk Islam untuk memasak masakan halal sesuai dengan syariat Islam. Hal ini diberikan oleh masyarakat mayoritas dengan tujuan agar masyarakat minoritas tidak khawatir dengan kualitas makanan dan turut menikmati kebahagiaan dalam melaksanakan tradisi warisan nenek moyang mereka. Sikap toleransi seperti ini harus tetap dijaga dan dijadikan contoh bagi masyarakat dimanapun untuk menciptakan keberagaman yang harmonis.

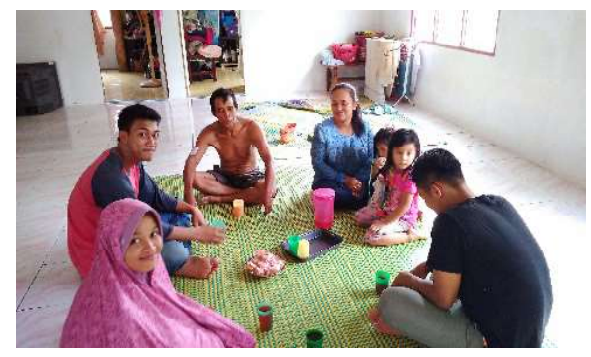

Gambar 6, Berkunjung ke rumah Pak Lamat yang beragama Katolik namun anak dan cucunya sudah berpindah agama menjadi Islam

Bahkan terdapat penduduk yang masih satu keluarga dan tinggal bersama namun memeluk agama yang berbeda. Perbedaan agama dalam satu keluarga dan tinggal dalam satu atap ini bagi masyarakat di Kampung Kendaie Lundu sudah menjadi hal yang biasa. Hal tersebut terjadi karena faktor pernikahan dan juga sukarela dari orangorang yang berpindah agama menjadi Islam. Para orangtua di Kampung Kendaie Lundu tidak melarang keluarganya dan anak-anaknya untuk memeluk keyakinan yang berbeda, begitu juga sebaliknya. Justeru tidak jarang orangtua yang memeluk agama selain Islam mendukung ketika anaknya mempelajari Islam. Anggota keluarga yang berbeda keyakinan tidak menganggap hal tersebut sebuah masalah yang bisa membatasi hubungan dalam kehidupan mereka sehari-hari, baik dalam hal makanan, pakaian, bahkan pada proses menjalankan ibadah sesuai agama yang dianutnya.

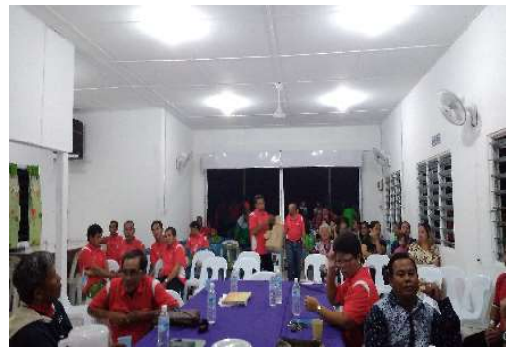

\section{Gambar 7, Musyawarah Masyarakat Kampung Kendaie}

Suku Dayak Bidayuh Lara yang menjadi masyarakat asli yang tinggal di Kampung Kendaie Lundu juga mempunyai acara adat seperti suku Dayak lainnya. Acara adat dan kepercayaan pun masih dilakukan secara rutin. Semua masyarakat dari berbagai kalangan dan keyakinan mengikuti kegiatan-kegiatan adat yang diselenggarakan secara gotong-royong. Namun dalam menyediakan hidangan dalam melaksanakan upacara adat, masyarakat mayoritas yang belum memeluk Islam mempersilahkan saudarasaudara mereka yang sudah memeluk Islam menjadi juru masak dan panitia dapur. Hal ini dilakukan karena mereka percaya bahwa orangorang Islam lebih bersih dalam memasak dan menyediakan makanan.

Pak Cik Berahim (64) yang menjadi imam surau mengatakan,

"Sudah lama masyarakat Kampung Kendaie Lundu berbaur dan bersama-sama dalam menjalankan kegiatan sosial. Meskipun agama Islam masih sangat sedikit di anut oleh orang-orang di Kampung Kendaie Lundu, masyarakat mayoritas yang belum memeluk Islam sangat menghargai dan menghormati orang-orang yang beragama Islam. Bahkan dalam acara-acara kampung, pertemuan dan musyawarah, orang-orang yang beragama Islam selalu dimintai untuk menjadi juru masak dan panitia dapur yang bertugas untuk menyiapkan konsumsi dalam kegiatan yang akan diselenggarakan".

Menurut keterangan Pak Cik Haikal (47), seorang mualaf dan tokoh kampung.

"Sejak saya masih muda memang kami sudah melakukan gotong-royong seperti ini. Para orangtua kami yang mengajarkan bahkan sebelum saya menjadi mualaf. Orangtua kami mengajarkan bahwa orangorang muslim lebih bersih dalam menyiapkan makanan. Karena ajaran ini hal seperti ini masih dilakukan sampai sekarang. Bahkan hal seperti ini juga dilakukan dalam kegiatan-kegiatan kebudayaan yang sebenarnya tidak berkaitan dengan agama, seperti tradisi orang-orang Dayak ketika melaksanakan upacara adat dan Gawai Dayak. 


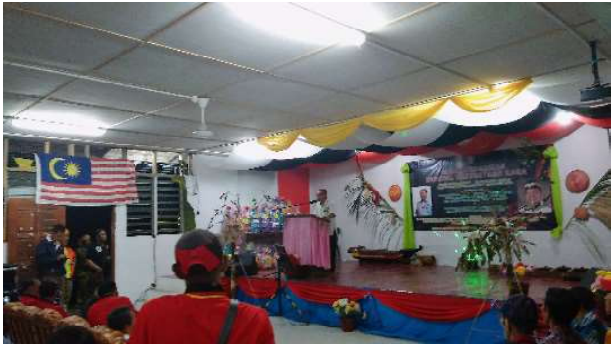

Gambar 8, Gawai Dayak

Setiap tahun upacara adat dilakukan namun tetap orang-orang Islam menjadi panitia dapur dan uniknya masyarakat mayoritas juga melarang untuk menyediakan makanan haram menurut ajaran Islam seperti memasak babi dan menyediakan tuak dengan alasan tidak ingin memberi batas dalam merayakan hari bahagia mereka tersebut, meskipun ada ruang khusus yang di sediakan untuk mengolah dan menyajikan makanan dari daging babi dan tuak dengan lokasi yang terpisah dari lokasi utama.

Meski mayoritas masyarakat di Kampung Kendaie Lundu belum memeluk Islam dan tidak melarang memakan daging babi. Masyarakat di sana tidak boleh sembarangan memelihara babi. Babi peliharaan harus dipelihara di dalam kandang yang terkunci dan tidak boleh dibiarkan bebas berkeliaraan di kampung. Hal ini sudah menjadi maklumat kampung untuk menjaga perkebunan mereka agar tidak dirusak oleh babi peliharaan dan sebagai upaya untuk menghormati orang-orang yang beragama Islam atas dasar musyawarah. Bahkan menurut keterangan Pak Cik Berahim, ada peraturan yang menyatakan bahwa jika ada ditemukan babi tidak di kandang dan berkeliaran, maka siapapun boleh membunuhnya dan pemilik babi tersebut tidak boleh marah bahkan menuntut ganti rugi apapun.

Meski terlahir sebagai masyarakat adat dan tinggal di pedalaman, sikap pluralis pada masyarakat Dayak Bidayuh Lara mencerminkan kemajuan sosial dan pemikiran yang melampaui dirinya sebagai masyarakat adat dan identik dengan orang kampung. Hal tersebut sesuai dengan tujuan para pendukung teologi pluralis yang menyebutkan bahwa pluralis bukanlah keseragaman bentuk agama, karena gagasan pluralisme agama berdiri di antara pluralitas yang tidak berhubungan dan kesatuan monolitik. Dalam pandangan pluralis, setiap agama merupakan ekspresi keimanan terhadap Tuhan (Schuon, 1987). Dalam bentuk pengekspresian terhadap keyakinan kepada Tuhan inilah yang melandasi masyarakat Kampung Kendaie Lundu tidak memberi batasan-batasan dalam kehidupan sosial dalam perbedaan keyakinan yang dianut. Agama adalah percaya kepada Tuhan yang Maha Esa dan hukum-hukum yang diwahyukan kepada utusan-Nya bagi kebahagiaan hidup di dunia dan akhirat (Ghazali, 2009).

\section{E. Pluralitas Sosial Masyarakat Kendaie Lundu}

Pluralitas sosial berarti segala aspek perbedaan yang mencakup keyakinan dan budaya dalam kehidupan sehari-hari yang dialami oleh masyarakat Kampung Kendaie Lundu. Meskipun sebagai masyarakat yang majemuk dengan keberagaman agama, suku dan budayanya. Masyarakat Kampung Kendaie Lundu pada umumnya memiliki ikatan sosial yang kuat sehingga perbedaan-perbedaan yang ada pada diri mereka tidak memberi batasan bahkan tidak menimbulkan konflik dalam melakukan aktivitas sehari-hari.

Dalam menjalankan aktivitas dan kegiatan sehari-hari, hampir tidak terlihat adanya perbedaan yang menonjol pada masyarakat di Kampung Kendaie Lundu. Baik perbedaan antara Islam dan bukan Islam, perbedaan antara orang Dayak Bidayuh Lara dengan orang Dayak Selako dan Iban, dan perbedaan dengan suku-suku lain seperti Melayu, Bugis, dan Sunda. Hal ini disebabkan Bahasa yang mereka gunakan untuk berkomunikasi dalam kehidupan sehari-hari sama yaitu menggunakan Bahasa Dayak Bidayuh Lara, bahasa Bakati, bahasa Selako, dan bahasa Melayu.

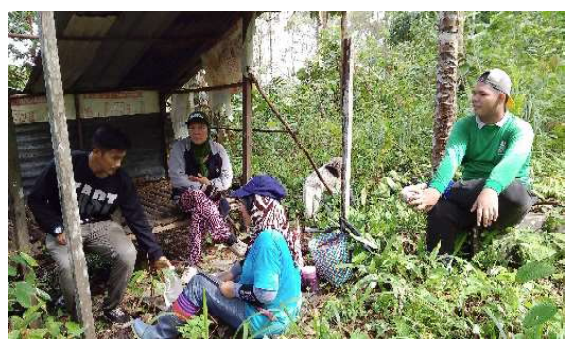

Gambar 9, Ibu-Ibu non muslim memakai jilbab

Potret-potret pluralitas sosial terjadi karena diajarkan dan diwariskan oleh para orangtua kepada anak-anaknya dan menjadi doktrin bagi pendidikan dasar di Kampung Kendie Lundu. 
Sehingga anak-anak tumbuh sebagai orang-orang yang pluralis. Potret pluralitas dalam banyak kesempatan, sering dijumpai ibu-ibu dari suku Dayak yang tidak memeluk Islam memakai pakaian tertutup lengkap dengan jilbab sebagai perlengkapan mereka untuk pergi berkebun. Hal tersebut dilakukan mereka dengan alasan bahwa pakaian tertutup khas pakaian muslimah ini melindungi mereka dari serangga dan tanaman liar selama berada di kebun, dan mereka merasa aman.

Selain itu, banyak juga masyarakat di sana yang sudah memeluk Islam tapi tetap memelihara anjing dengan berbagai alasan. Bukan mereka tidak mengetahui bahwa terdapat najis pada anjing tersebut, mereka paham dan sadar bahwa dalam tubuh anjing terdapat najis, jika terkena najis tersebut harus membersihkan dengan tujuh kali basuhan air dan salah satunya menggunakan lumpur atau tanah. Memelihara anjing ini sudah menjadi kebiasaan, baik dilakukan oleh orangorang yang tidak beragama Islam, dan juga orangorang yang sudah beragama Islam. Bagi mereka anjing mempunyai manfaat yang banyak, selain menjadi keamanan kampung, anjing juga dianggap teman yang paling setia menemani aktivitas mereka, terutama ketika berada di kebun.

Pluralitas sendiri memiliki arti kondisi keberagaman (M.Tuwah, 2001). Sejalan dengan fenomena yang terjadi di Kampung Kendaie Lundu, keberagaman tidak hanya mencakup perbedaan agama, melainkan keberagaman dalam suku dan budaya. Meskipun sebagai kampung yang penduduknya belum terlalu ramai, keberagaman tersebut justru menghidupkan Kampung Kendaie Lundu menjadi kampung pedalaman yang lebih berwarna.

Meskipun sama-sama masyarakat perbatasan, dibandingkan saudara-saudara mereka yang berada di Sajingan dan Aruk Indonesia, masyarakat Kampung Kendaie Lundu cenderung lebih mudah menjangkau fasilitas umum yang memadai seperti ketersediaan rumah sakit dengan segala fasilitasnya di Kota Lundu yang jaraknya tidak terlalu jauh dan juga sekolahsekolah yang menyediakan segala peralatan yang mendukung untuk proses belajar-mengajar beserta guru-guru yang kompeten. Sedangkan di Sajingan dan Aruk, fasilitas umum seperti gedung sekolah sangat memprihatinkan, bahkan jika ada penduduk setempat yang sakit, maka jarak ke rumah sakit terdekat adalah di Kota Sambas yang berjarak 93 kilometer, tidak jarang jika peralatan tidak memadai pasien akan dirujuk ke rumah sakit di Pontianak yang berjarak 319 kilometer dengan jarak tempuh tujuh jam.

Kesenjangan sosial masyarakat perbatasan di daerah perbatasan Kampung Kendaie Lundu dengan masyarakat Aruk dan Sajingan di wilayah Indonesia ini sama seperti kesenjangan sosial yang terjadi di daerah perbatasan Badau di Indonesia dan perbatasan Lubok Antu di Malaysia. Jika membandingkan daerah perbatasan antara Badau wilayah Indonesia dan Lubok Antu wilayah Malaysia pasti akan menimbulkan kesenjangan yang signifikan bagi masyarakat itu sendiri. Bukan tidak beralasan, hal ini dapat dilihat dari susahnya wilayah Badau dari jangkauan ibu kota Kalimantan Barat, Pontianak. Juga dari segi pembangunan infrastruktur, Badau masih tertinggal dari pembangunan yang dilakukan oleh Malaysia di daerah perbatasannya, sehingga susahnya suplay kebutuhan pokok sampai di Badau, masyarakat Badau lebih memilih menggunakan barang-barang dari Malaysia. Hal itu disebabkan karena dari Badau menuju Malaysia lebih mudah, selain jarak yang dekat, bagusnya jalan dan transportasi lebih memungkinkan masyarakat Badau untuk pergi ke Malaysia. Tidak hanya itu, berdasarkan survey dan wawancara terhadap masyarakat lokal Badau menginfokan bahwa barang-barang yang di beli di Malaysia jauh lebih murah (Efendi, 2017).

Pembicaraan mengenai wilayah perbatasan tidak dapat dipisahkan dari kesan terisolir, terbatas, dan jauh dari perhatian pemerintah. Kesan ini tidak dapat disalahkan karena demikianlah adanya di hampir seluruh wilayah perbatasan Indonesia. Kondisi memprihatinkan ini disebabkan oleh kesalahan paradigma yang dibangun secara akademis dan praktis yang menganggap wilayah perbatasan berada di pedalaman atau pinggiran yang sekaligus diposisikan di belakang atau terbelakang sehingga tidak penting diperjuangkan dalam perspektif yang bias modernism (Permatasari, 2014).

Dengan segala problematika yang ada di perbatasan, Indonesia juga terus berupaya untuk membenahi daerah perbatasan. Pemerintah daerah dan pemerintah pusat telah mendorong perkembangan wilayah perbatasan menuju ke 
arah yang lebih baik dengan melakukan berbagai upaya melalui program-program dan kucuran dana dari berbagai instansi pemerintahan. Targettarget pembangunan dari pemerintah diarahkan untuk menunjang keberlangsungan hidup yang lebih baik dan berkehidupan yang layak bagi setiap Warga Negara Indonesia. Bahkan pemerintah telah membuka kesempatan kepada investor untuk ikut berpartisipasi dalam pembangunan di daerah pedalaman, terpencil, dan perbatasan seperti di Kabupaten Kapuas Hulu yang mencakup Badau dan sekitarnya (Zaenuddin, 2013).

Terdapat fenomena unik yang berkaitan dengan nasionalisme masyarakat perbatasan dari Indonesia yang tinggal di Kampung Kendaie Lundu. Dalam mempertahankan dan menerapkan sikap nasionalismenya, ada seorang laki-laki bernama Pak Lamat, beliau seorang Dayak Bidayuh Lara yang berkewarganegaraan Indonesia. Pak Lamat berasal dari Sajingan Indonesia, mempunyai istri berkewarganegaraan Malaysia dan sudah menikah selama 30 tahun. Selama 30 tahun tersebut Pak Lamat tidak mau mengganti kewarganegaraannya menjadi Malaysia meskipun setiap bulan beliau harus lapor ke Pos Lintas Batas Negara (PLBN) di Aruk untuk absen menggunakan paspor biasa. Meskipun istri dan anak-anaknya berkewarganegaraan Malaysia, Pak Lamat tetap ingin dan akan menjadi warga Indonesia. Hal tersebut dilakukan Pak Lamat semata-mata karena ingin menghormati keluarga dan saudarasaudaranya yang dulu ikut berjuang mempertahankan wilayah Sajingan tetap menjadi bagian dari Indonesia.

Sebagai masyarakat adat yang plural, masyarakat Kampung Kendaie Lundu juga mempunyai dan menjalankan tradisi-tradisi sosial seperti gotong-royong ketika akan dilaksanakannya acara kampung, dan gotongroyong dalam berkebun. Tanpa diminta masyarakat di sana sudah tahu apa yang harus dilakukan jika akan diadakan acara kampung. Begitu juga saat ada tetangga mereka yang akan membuka lahan dengan menebas ilalang saat datangnya musim tanam padi atau panen durian. Hal ini dilakukan secara sukarela dan saling bergantian. Namum khusus dalam perkebunan sawit atau sahang (merica) yang memiliki nilai ekonomis yang lebih tinggi, sistem yang digunakan dalam membantu kegiatan di perkebunan tersebut sudah memakai sistem upah, dengan memberikan nilai upah Ringgit Malaysia untuk pekerjaan tertentu seperti panen sahang, panen sawit, dan membersihkan perkebunan dari ilalang yang sering disebut dengan istilah Nebas.

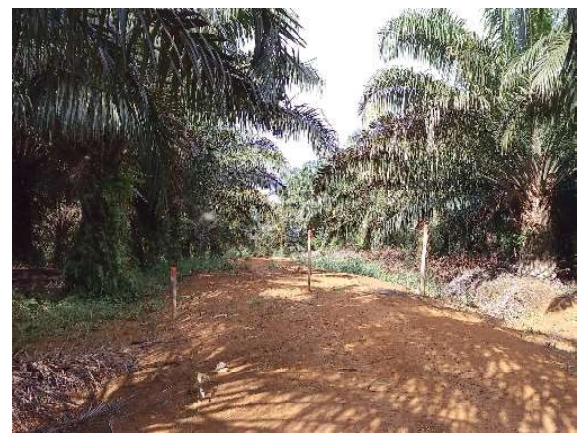

Gambar 10, Patok kayu perbatasan negara

Kampung Kendaie menjadi pemukiman terdekat dengan garis perbatasan Malaysia dan Indonesia. Garis perbatasan tersebut hanya berjarak kurang lebih 3 kilometer dari pemukiman warga. Keberadaan patok yang menjadi tanda perbatasan negara Malaysia dan Indonesia juga masih berada di perkebunan sawit milik warga Kampung Kendaie Lundu. Hal ini menunjukkan keseriusan pemerintah Malaysia dalam menjaga perbatasan negara dengan membuka pemukiman yang tepat berada di garis perbatasan sehingga tanpa disadari masyarakat menjadi pemantau utama yang berperan aktif dalam menjaga perbatasan. Lain halnya dengan Indonesia, wilayah perbatasan Indonesia justeru menjadi perkebunan sawit milik perusahaan, dan pemukiman penduduk berada jauh dari garis perbatasan sehingga pemantauan garis perbatasan Indonesia hanya dilakukan oleh pasukan TNI yang berpatroli hanya dalam waktuwaktu tertentu.

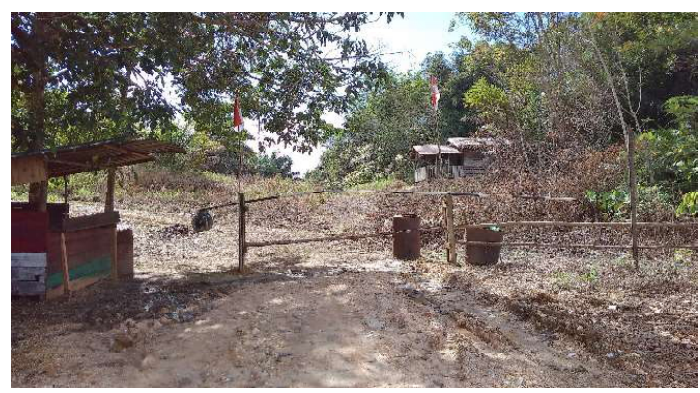

Gambar 11, Pos Pantau Perbatasan 
Pada garis perbatasan yang melintasi Kampung Kendaie Lundu juga terdapat Pos pantau Indonesia, namun menurut keterangan masyarakat setempat bahwa pos ini selalu kosong dan jarang ada TNI yang berjaga di sana. Kenyataan ini membuat masyarakat bisa berlalu lalang melintasi perbatasan dengan bebas. Oleh sebab itu menurut cerita masyarakat setempat bahwa sering terjadi pencurian yang dilakukan oleh orang Indonesia, mereka memanfaatkan kondisi perkampungan yang sepi dan tidak adanya penjagaan di pos perbatasan. Barangbarang yang sering menjadi target pencurian adalah kendaraan seperti mobil, motor, dan barang-barang elektronik di dalam rumah yang ditinggal pemiliknya pergi berladang.

Selain kasus pencurian, dengan lengahnya penjagaan di daerah perbatasan juga memberi celah bagi penyelundupan barang-barang ilegal dan narkoba. Menurut informasi dari masyarakat Kampung Kendaie Lundu bahwa sering ada orang asing yang melintasi perkampungan mereka untuk masuk ke Indonesia, masyarakat Kampung tidak bisa berbuat banyak karena banyaknya jalan di perkebunan sawit yang lepas dari pantauan warga setempat. Sehingga barangbarang illegal dan narkoba bisa dengan mudah masuk ke Indonesia, khususnya di wilayah perbatasan Kalimantan Barat hingga ke kota-kota di Kalimantan Barat.

Dengan realitas seperti ini tentu harus menjadi perhatian khusus bagi pemerintah Indonesia. Perbatasan yang menjadi garda terdepan bangsa harus segera diperhatikan. Sarana dan prasarana yang menunjang kedaulatan bangsa Indonesia harus segera dibangun agar masyarakat di daerah perbatasan Indonesia mendapatkan haknya sebagai warga negara Indonesia. Selain itu agar masyarakat perbatasan di Indonesia bisa segera mengikis kesenjangan sosial yang sudah terjadi sejak lama dengan saudara-saudara mereka yang berada di perbatasan Malaysia.

\section{F. Kesimpulan}

Pluralitas sejatinya menjadi bagian dalam kehidupan umat manusia dimanapun. Keberagaman yang mencakup segala aspek kehidupan sosial sudah menjadi satu-kesatuan dari manusia tanpa terkecuali. Namun pluralitas saat ini sering dipahami sebagai sebuah paham untuk memberi jarak bagi perbedaan dalam kehidupan masyarakat.

Namun dengan apa yang sudah dijelaskan mengenai pluralitas yang terjadi pada masyarakat adat Dayak Bidayuh Lara di Kampung Kendaie Lundu telah menjadi sebuah refleksi baru bagi penulis dalam melihat realitas pluralitas dalam kehidupan sehari-hari. Dimana perbedaan bukanlah sebuah alasan untuk memberikan jarak pada sebuah perbedaan di tengah-tengah masyarakat, atau bahkan menjadikannya sebagai alasan dari terjadinya sebuah konflik. Perbedaan justeru menjadi pewarna tatanan sosial yang membuat kehidupan masyarakat lebih indah.

Toleransi yang menjadi prinsip hidup masyarakat Adat Dayak Bidayuh Lara harusnya menjadi contoh bagi masyarakat luas. Dengan menjunjung tinggi toleransi maka kita akan terhindar dari konflik apapun. Hal ini akan tercipta jika kita saling menerima dan saling mengasihi, baik atas nama ajaran agama ataupun atas nama kemanusiaan.

Fenomena pluralitas yang terjadi di Kampung Kendaie Lundu harus dijadikan contoh dan kajian, agar hal-hal positif dalam keberagaman di masyarakat bisa menjadi pelajaran-pelajaran yang terus diperhatikan. Pluraliatas berarti memahami bahwa setiap diri dari manusia adalah bagian dari keberagaman, baik agama yang dianut, suku yang menjadi identitas, dan budaya sebagai refleksi dari asal-usul seseorang atau kelompok tersebut.

\section{UCAPAN TERIMAKASIH}

Syukur Alhamdulillah atas pertolongan Allah SWT Tuhan yang Maha Esa sehingga penulis mendapat kesempatan pengalaman yang luar biasa selama melakukan kegiatan di perbatasan Indonesia dan Malaysia. Terimakasih kepada orangtua di kampung yang selalu mendoakan sehingga dalam menjalankan aktivitas penulis selalu mendapat kemudahan. Terimakasih kepada Dr. Zaenuddin, MA, selaku guru yang paling berjasa dalam memberikan sarana dan prasarana, serta bimbingan dalam melakukan kegiatankegiatan di daerah perbatasan, dan telah mengajarkan menulis artikel penelitian baik dari lisan maupun tulisannya. Terimakasih untuk Lembaga Dakwah Hikmah yang telah memberikan wadah untuk pengalaman berharga dalam Program Pengabdian pada Masyarakat di pedalaman Sarawak. Terima kasih kepada 
masyarakat Kampung Kendaie Lundu yang sudah menganggap kami seperti keluarganya sendiri. Terima kasih juga kepada IAIN Pontianak yang menjadi tempat penulis belajar selama kuliah. Semoga kebaikan-kebaikan selalu menyertai orang-orang yang menjadi bagian dari cerita perjalanan hidup penulis selama kuliah. Dengan ini saya berharap semoga apa yang penulis sampaikan lewat makalah ini menjadi sesuatu yang bermanfaat bagi pembaca dimanapun berada. 
Amilda. (2011). Menjadi Melayu yang Islam: Sebuah Politik Identitas Etnis Minoritas dalam, Menghadapi Dominasi Negara dan Etnis Mayoritas. Annual Conference on Islamic Studies: Fakultas Ushuluddin dan Pemikiran Islam. IAIN Raden Fatah Palembang

Bakar, A. (2015). Konsep Toleransi Dan Kebebasan Beragama. Media Komunikasi Umat Beragama. Vol.7, No. 2.

Efendi, Z. (2017). Penyiaran Islam di Perbatasan "Badau" Indonesia-Malaysia. Panangkaran.

Elizabeth K. Nottingham. (1992). Agama dan Masyarakat. Jakarta : Rajawali Press

Ghazali, A. M. (2009). Argumen Pluralisme Agama: Membangun Toleransi Berbasis Al-Qur'an. Depok: Kata Kita

Liliweri, A. (2009). PRASANGKA \& KONFLIK, Komunikasi Lintas Budaya Masyarakat Multikultural. Yogyakarta: PT LKiS Printing Cermelang.

Lotaan, J.U. (1975). Sejarah Hukum Adat dan Adat Istiadat Kalimantan Barat. Jakarta: Bumi Restu.

M.Tuwah, Subardi, DKK. (2001). Islam Humanis. Jakarta : PT. Moyo Segoro Agung

Margono. (2005). Metodologi Penelitian Pendidikan. Semarang: Rineke Cipta.

Moleong, L. J. (2015). Metodologi Penelitian Kualitatif. Bandung: Remaja Rosdakarya.

Permatasari, I. A. (2014). Politik Identitas Masyarakat Perbatasan Indonesia-Malaysia: Kasus Badau di Kapuas Hulu, Kalimantan Barat. Kawistara. Vol.4, No. 3.

Prasojo, Z. H. (2009). The Muslim Dayak Katab Kebahan of Melawi district, West Borneo, globalization, religion, and ethnicity in indigenous community identity. The 4th Asian Graduate Forum. Singapore: ARI-NUS.

Prasojo, Z. H. (2013). Dinamika Masyarakat Lokal di Perbatasan. Jurnal Walisongo. Vol 21. No 2.

Pluralitas Agama Pada Masyarakat Adat ...
Rufinus, A. (2000). Dayak Islam di Kalimantan Barat, fenomena dan implikasi keberadaannya. Dayak Islam di Kalimantan Barat: Sebuah Kolokium Dayak Islam di Kalimantan Barat. Pontianak: STAIN Pontianak Press.

Schuon, F. (1987). Mencari Titik Temu AgamaAgama. Jakarta: Yayasan Obor Indonesia

Shihab, A. (1999). Islam Inklusif: Menuju Sikap Terbuka dalam Beragama. (Bandung: Mizan).

Sukmadinata. (2013). Metode Penelitian Pendidikan. Bandung: Remaja Rosdakarya.

https://postcode.my/sarawak-lundu-kampungkendaie-94500.html (diakses 2020).

Data penduduk Kampung Kendaie 2017 